\title{
Withdrawal by Subject
}

National Cancer Institute

\section{Source}

National Cancer Institute. Withdrawal by Subject. NCI Thesaurus. Code C49634.

An indication that a study participant has removed itself from the study. 